\title{
The Management of Forest and Deforestation, Mitigation, and Adaptation of Climate Change in Madagascar
}

\author{
Njaratiana Mario Arthur Veloํ, Jocelyne Zafitsara² \\ ${ }^{1}$ Department of Public Administration, Zhejiang Normal University, Jinhua, China \\ ${ }^{2}$ College of Teacher Education, Zhejiang Normal University, Jinhua, China \\ Email: velomarioarthur@gmail.com, zafitsara.jocelyne@gmail.com
}

How to cite this paper: Velo, N.M.A. and Zafitsara, J. (2020) The Management of Forest and Deforestation, Mitigation, and Adaptation of Climate Change in Madagascar. Open Access Library Journal, 7: e6451. https://doi.org/10.4236/oalib.1106451

Received: May 23, 2020

Accepted: June 9, 2020

Published: June 12, 2020

Copyright $\odot 2020$ by author(s) and Open Access Library Inc.

This work is licensed under the Creative Commons Attribution International License (CC BY 4.0).

http://creativecommons.org/licenses/by/4.0/

\section{(c) (i) Open Access}

\begin{abstract}
Madagascar is on the first conservation priority for high rates of deforestation and endemism. Deforestation has been extensive, but the impacts of forest loss on biodiversity have not been well quantified. Deforestation is a phenomenon contributor to species, biodiversity's extinction, and the disappearing of tropical forest accelerates the rate of destruction and accelerates climate change degradation. Madagascar's forests and its biodiversity are considered as one of the most biologically rich and unique in the world, but due to this deforestation, the endemic species and biodiversity of Madagascar are endangered and indeed, this phenomenon has changed Madagascar the green Island into the red Island. The aim of this paper is to highlight what Madagascar needs, what the country has and what are the barriers to mitigate deforestation and how is the impact of climate change. The findings of this study show that Madagascar has a total land area of 59,199,127 ha; in 2010, the country has 4,628,241 ha of primary forest with $16,450,024$ of tree cover. However, this statistic continues to decrease gradually in 2018 represented by $4,060,522$ ha of primary forest, and has lost 567,719 ha of its forest; only $13,772,127$ ha of tree cover has been registered. It is as well stated that apart from the lack of funding, timber logging and fuel wood, the ancestral practices are locally known as "Tavy" which is the most destructor of primary forest in Madagascar. This phenomenal calamity led to extinct thousands of Madagascar species and its biodiversity, and contributes to increasing the heat of this planet and one of the responsible for the acceleration of climate change. This paper illustrates how Madagascar adapts to the impacts of climate change and how the country contributes to its commitment to the Paris Agreement.
\end{abstract}




\section{Subject Areas}

Environment, Climate Change

\section{Keywords}

Deforestation, Climate Change, Reforestation

\section{Introduction}

The extinction of species and climate change are problems facing by every $\mathrm{Na}$ tion. Around the world, there are many factors that are considered contributing to the planet degradation such as the greenhouse gas emissions which contribute to a global externality [1], the pollution emitted by chemical factories, but the principal challenge faced by climate change is deforestation. The deforestation is becoming a fundamental factor that destroys the forest and disappearing of species, endemism, and natural biodiversity. On the other hand, the excessive need for trees is a major cause of environmental damage and climate change. Loss of forest cover always affecting climate and the global demand for products like wood, paper, beef, and palm oil continues to rise and increase day by day, therefore, it is the need for these companies which led to reduce the forest area and do not yet stop to decrease in the world [2]. The government, and Non-Governmental Organizations are working to the same purpose to keep and save this planet far from climate change and trying to mitigate the impact of climate degradation around the world.

In Africa, around 22 percent is forest and woodland, and only a small percentage of this acreage is protected [3] and the Basin of Congo is considered as Africa's largest contiguous forest and the second-largest tropical rainforest in the world that covers about 695,000 square miles [4]. Africa is among the vulnerable continent affected by climate change [5] and living under its impacts. Africa has less equipment to fight and to adapt to the impact of climate change [6]. Most of the African countries depend on the forest to survive and to make their daily life because of poverty, lack of developed and modern technologies, lack of effective and inclusive policies to forest protection, and lack of education regarding environment protection among the factors behind the massive environmental degradation and deforestation in Africa. The deforestation has considered the main factor contributing to climate change after greenhouse emissions in Africa and Madagascar is one of the African countries that is classified among the vulnerable and the most destructor of forest in Africa.

The daily survival of the population of Madagascar usually depends on the use of natural resources such as forests, rivers, seas, and others. Because of lack of education in certain places of the country, most Malagasy never have an option to become doctors, sports stars, factory workers, or secretaries; they must live off the land that surrounds provide to them; they are contributing of the use of 
whatever resources they can find. Their poverty costs the country and the world through the loss of the island's endemic biodiversity and its forests.

Madagascar is ready for the conservation of its unique biodiversity and considered an international significance [7]. As the case of Madagascar, it is known as the country of plenty biodiversity and unique in the word, a report discovered that $80 \%$ of more than 170 recorded tree species in its forests type are found only in Madagascar and with $60 \%$ of biodiversity which is only existing in Madagascar [8]. Unfortunately, actually, that bio-diversification is on its way to losing its primary originality [9] and climate change affects Madagascar's forest ecosystems directly [10]. The scientist's environmentalist analyzed that, since the 1950s to 2000s, Madagascar's forests surface are decreased to $40 \%$, with a reduction in core forest superior to $1 \mathrm{~km}$ from a non-forest edge of almost $80 \%$. The extinction of biodiversity is caused majorly by deforestation and other human activities and the natural calamities. Numerous deforestation processes involved in the individual growth and population dynamics of these organisms are closely linked to climate. Consequently, the climate degradations predicted for Madagascar's regions will have a considerable impact on its future generation. There are two major kinds of resource degradations existing in Madagascar: one is the natural catastrophe such as cyclones, floods, droughts but the second catastrophe is always the fruit of the human activities characterized by the deforestation, the ancestral practices, slash and burn so on. Deforestation is one of the factors that encourage the acceleration of climate change in the world and discussed in the Paris Agreement. The ignorance of impacts on climate change leads the non-educated people to practice more and increase the rate of deforestation in certain places in Madagascar. This paper has a structure to investigate the capacity of adaptation on climate, the barriers and needs of Madagascar on climate change mitigation and how the Paris Agreement is applied conforming to the national policies of climate change mitigation? Therefore, What Madagascar has in its capacity; what are their needs and their barriers to adapt and mitigate to climate change?

\section{Methods}

The study area is located in the South-eastern in Africa that is Madagascar. This country is characterized by high rate of traditional agriculture and overexploitation of its forest with its different forms. This study was made by the understanding of a systematic review of literature regarding deforestation and climate change. Also, used an approach known as "integrated conservation and development approach". The premise of the integrated conservation and development approach is to give consideration on the local people living near the forest to get benefits from the forest and must be participants in conservation and must contribute to the mitigate climate change. Having forests protected and conserved, its biodiversity and water resources can have significant benefits on the mitigation of climate change. In fact, these actions may contribute to the strengthening of carbon stocks. 


\section{Results}

\subsection{Deforestation Statistics for Madagascar}

Madagascar lost its forest year by year. The country disposes a total land area of $59,199,127$ ha, and the extent of primary forest cover and tree cover for Madagascar are represented as follows: in 2010, the country has 4,628,241 ha of primary forest with $16,450,024$ of tree cover. Unfortunately, this statistic continues to decrease gradually in 2018 represented by $4,060,522$ ha of primary forest, which means the country has lost 567,719 ha of its primary forest, and only remaining with $13,772,127$ ha of tree cover. Actually, in total Madagascar has $29 \%$ of its primary forest and only $23.3 \%$ of tree cover [11]. Since 2017, according to the World Database on Protected Areas maintained by the United Nations Environment World Conservation Monitoring Centre (UNEP-WCMC) confirmed that in 2017 the surface of land protected is 5.6\% [12].

\subsection{Capacities of Madagascar}

\subsubsection{Population}

The first capacity that Madagascar has is the population. The population of Madagascar is actually estimated about 25 million and it would be the first power to fight the issue with climate change. The population is the major solution, a good weapon to bring a change and transform society [13] in particularly to fight on climate degradation, which that means without population without change or transformation society. The society might be changed its social structure by its population and its institutionalization [14] and a social change are always gradually and usually remarkable after a duration might be months or years. Social change agrees with the transformation of behavior, social institution and might be culture also, but it is depending on the time [15].

\subsubsection{Organization and Association}

It has also organization and association with the aim to protect the environment and promote environmentally sustainable. In 1993, the international organizations with Madagascar's government, including wildlife Conservation Society, CARE International Madagascar, and the Peregrine Fund have built a plan for the park's design that might provide the needs of the fauna and flora and people. Moreover, the plan also includes taking care of the environment of Madagascar and its plenitude of species [16].

After researching the situation, these organizations found that the most important areas for biological diversity were those that were also least accessible including park. The accessible areas were not included in the park, encouraging sustainable development by allowing locals to harvest timber and non-timber forest products. For example, one of the biggest primary forest in the north-east of Madagascar called Masoala forest gained financial aid fund and the project is to develop a community with a principal aim to grow rain forest butterflies and sell them to butterfly zoos around the world because to mitigate climate change 
is not only to save human beings but also to save animal lives and its generations [17].

These areas are considered as a savior for the local people because it could furnish non-destructive livelihood, sustaining the forests around the park as a rich source of natural resources and a buffer to the park. Other benefits to communities would arise through ecotourism in the park. In 1997, the Wildlife Conservation Society and CARE International have continued to work in the north-east part of Madagascar and implemented some infrastructures for developing tourism, and also developing park management plans which are based on scientific research area in the point of view to work with the local communities.

Since the commencement of Madagascar's Environmental Action Plan, Madagascar has accepted eight new protected areas located in 6,809 square kilometers. And it is the country's new National Association for Protected Area Management has committed and taken over the control and management of numerous parks. As Lisa Dean of CARE International Madagascar stated during the inauguration of the park at Masoala, "The approval of the Masoala National Park represents a huge commitment by the Madagascar government, done against all odds. Indeed, for Masoala and its other protected areas, Madagascar can be proud of its pathway efforts to develop a pertinent, viable approach to 'parks for wildlife and for people'." Therefore, their commitment is to make sure that the existing parks, as well as reserves, will keep going far into the future to furnish habitat for Madagascar's fabulous and endemic biodiversity and the resources for well sustainable development and good future for Madagascar's people [18].

\subsubsection{Forests}

The planet's land surface is covered by $30 \%$ of forests and stated that $90 \%$ considered as a home of the world's land-based animals, plants, insects and birds. In other words, forests are the world's largest, and each year they are known to absorb 2.4 billion tons of carbon. The environmentalist proved that each year, six million hectares or more of the primary forest is lost on this planet and this loss is remarkably due to different forms of deforestation. Halting this issue is seen as strength to keep the global temperatures less than $2^{\circ} \mathrm{C}$. The scientists always warming the alarm that destruction of the forest should be reduced by $50 \%$ at the end of 2030 otherwise this planet is going to trap in fatal catastrophe, and stopping deforestation is the best solution to achieve the target [19].

Although Madagascar has forests, unfortunately, some of the people do not know the role and the importance or benefits to mitigate climate degradation. Globally as a considerable warehouse of carbon, forests play a huge role in influencing the Earth's climate. Actually, forests are the natural catalysts of this planet, because the technologies for capturing the $\mathrm{CO}_{2}$ emissions are in the new agenda for climate change but not yet operational or functional [20]. The scientist stated that forest plants and soils drive the global carbon cycle by sequester- 
ing carbon dioxide through photosynthesis and releasing it through respiration. When the uptake of carbon dioxide (photosynthesis) is greater than losses via respiration, harvest and management then forest store carbon [21].

The Masoala Peninsula is among Madagascar's last largest places and it is one of the latest large areas of lowland rain forest in the island, including habitat for many endemic species and biodiversity extremely rare in the world like the famous red-ruffed lemur, the serpent eagle, the red owl, the helmet vanga, the scaly and short-legged ground rollers only known in this area. This area is known also for its diverse and beautiful forests meet white sand beaches, mangroves, fringing coral reef, and oceans and bays provide breeding habitat for humpback whales, dolphins, and sea turtles. Coral reefs observed around Masoala are a part of the most natural and diverse that Madagascar has to offer.

Forgiving more consideration at the values of environment and its protections, also to contribute at the mitigation of climate change, the government of Madagascar had decided to strictly protect this area to become a park with more than 3,000 square kilometers had chosen to be protected and simultaneously provide for the needs of 45,000 human inhabitants.

Sadly, a large part of Madagascar has been destroyed gradually by the action of small farmers and herdsmen. Human populations have grown long beyond the point at which these activities can be practiced without permanent destruction.

The loss of habitat caused by deforestation is the prime major threats to Madagascar's wildlife. Although there is no exact number of forest loss it is estimated that Madagascar remains only 10 percent of its forests and 1 to 2 percent of its remaining forests are destroyed and burns each year [22].

\subsubsection{Rivers}

The rivers around Madagascar serve respectively as a rich fishery and an important source of income for villagers. Unfortunately, fishing is poorly regulated. Madagascar has numerous rivers; these major rivers are the Betsiboka, Tsiribihina, Mangoky, and Onilahy rivers [23]. It is stated that most of these rivers are not exploited to produce energy for solving the needs of the population in energy. These rivers are usually using for the basic daily life of the people like fishing, and serve as a way to move from a position to another position but not used as an energy source.

The energy provided by rivers is poorly considered in Madagascar because only 3 dams are functional and operational in this country that was built by a French firm [24]. These dams are less helpful for the country because of its productions. The energy needs by the population are highly increased because of demographic explosion and unfortunately, dam infrastructures are old that provoke a low energy product in Madagascar [25]. Having rivers are among the solutions to transform our society's needs because for example having hydroelectric or hydropower energy is a way to promote sustainable energy because this technique does not need fossil fuel to make it operational [26]. 


\subsubsection{Madagascar' Seasons}

How is Madagascar's climate? The upland core of the island is comprised of two sub-regions. One, the Central Highlands has several summits above $2600 \mathrm{~m}$ and an average elevation of $1500 \mathrm{~m}$. The other sub-regions in the Middle West, where altitudes average is $1000 \mathrm{~m}$, are with few points higher than $1500 \mathrm{~m}$ [27]. In terms of season, highland Madagascar has six provinces and has a tropical climate tempered by altitude with a distinct seasonality of rainfall, which means each province has its own climate. For instance, in the center part of Madagascar such as the capital Antananarivo, Antsirabe, Fianarantsoa has a five-month hot and humid period set off by a cooler and drier season of about seven months. The average temperature in July at the height of the cool season is $14.4^{\circ} \mathrm{C}$. The lowest monthly average temperature is $26.3^{\circ} \mathrm{C}$.

In Toamasina located in the north-east part of Madagascar, during a year it faces four seasons represented by rain, humidity, sun and wind seasons. The summers are long, hot, oppressive, wet, and the winters are comfortable, muggy, and clear. Over the course of the year, the temperature typically varies from $17.6^{\circ} \mathrm{C}$ to $29.7^{\circ} \mathrm{F}$ and is rarely below $15^{\circ} \mathrm{C}$ or above $32^{\circ} \mathrm{C}$. The hot season lasts for 4.0 months, from December 7 to April 7, with an average daily high temperature above $28.6^{\circ} \mathrm{C}$. The hottest day of the year is February 7, with an average high of $29.7^{\circ} \mathrm{C}$ and a low of $23.65^{\circ} \mathrm{C}$ [28].

The average percentage of the sky covered at Toamasina city by clouds experiences extreme seasonal variation over the course of the year. The clearer part of the year in Toamasina begins around April and ending around November. In particularly, September is the clearest day of the year in this province, the sky is mostly clear, or partly cloudy $91 \%$ of the time [29]. The cloudier part of the year begins around the end of November and ends around mid-April. In particular, January is the cloudiest month of the year, the sky is mostly cloudy $79 \%$ of the time, and clear, or partly cloudy $22 \%$ of the time.

The chance of wet days in Toamasina varies very significantly throughout the year. The wetter season starts from mid-December and gets ending to mid-April, with a greater than $44 \%$ chance of a given day being a wet day. The chance of a wet day peaks over $75 \%$ during February. The drier season can take 7 or 9 months, which starts from the end of April to December. The smallest chance of a wet day is $13 \%$ in September.

The rainfall stockpiled in a sliding 31-day period centered on each day of the year. Toamasina experiences extreme seasonal variation in monthly rainfall. Rain falls throughout the year in Toamasina. The most rain falls during the 31 days centered on February, with an average total accumulation of 11.1 inches. The least rain falls is stated during September with an average of 0.9 inches.

\subsubsection{Wind}

The northern part of the island is characterized by strong winds for almost 6 months. The wind is the natural progression of air over the land and ocean. We can gain benefits from the wind and turn it to energy. The wind energy seems to 
be the ideal example to understand more the topic of energy renewables and to mitigate the degree of climate change. Wind energy is fueled by the wind, so it's a clean fuel source and doesn't pollute the air like power plants that rely on the combustion of fossil fuels, such as coal or natural gas. Wind turbines don't produce atmospheric emissions that cause acid rain or greenhouse gasses which means Electricity produced from the wind produces no $\mathrm{CO}_{2}$ emissions and therefore does not contribute to the greenhouse effect. Wind energy is depending on labor-intensive and can be used for energizing batteries, and also can be fused with a diesel engine to economize fuel whenever the wind is available. For many reasons the existing system like using fossil fuels, nuclear power, coal land is not a perfect one. Therefore, these structures must be changed in the future and we need to find the proper way to achieve a more sustainable system for energy usage without impacts on the climate.

\subsection{Madagascar's Government and Climate Change}

Madagascar is potentially known as one of the world's highest priority countries for biodiversity conservation due to its high number of rare fauna and floor and its exceptional species richness [30]; and these numerous unique species of plants and animals living in Madagascar are not comparable on the entire African continent, particularly above eighty percent of its species can be found nowhere else on Earth [31].

The government of Madagascar had also signed the Paris Agreement and submitted its new climate action plan to the UN Framework Convention on Climate Change (UNFCCC). Madagascar is one of the all nation members that are equally committed to contributing to mitigate climate change, as well as to reduce climate change vulnerability and promote adaptation measures. According to the Paris Agreement, Madagascar relies on the international community support to reach this objective through the United Nations Framework Convention on Climate Change (UNFCCC). According to the national contribution of the Republic of Madagascar for the mitigation of climate change estimated that In 2030, Madagascar aims to reduce approximately $30 \mathrm{MtCO}_{2}$ of its emissions of GHG, representing $14 \%$ of national emissions, compared to the BAU scenario, with projections based of GHG inventory from the year 2000 to 2010 and this reduction is additive to the 2 absorptions increase of the land use, land-use change, and forestry (LULUCF) sector, which estimated at $61 \mathrm{MtCO}_{2}$ (Metric tons of carbon dioxide) in 2030. "Therefore, the total of GHG absorption is expected at 32\%, compared to the BAU scenario." If Madagascar does not take its responsibilities, the total emissions will progress $214 \mathrm{MtCO}_{2}$ (Metric tons of carbon dioxide) in 2030 [32].

In summary, while Madagascar's unique climate and the various richness that it has are arguably enough to transform the energy to become a sustainable clean green energy if they are well exploited but at the same time, its exceptional richness needs to be preserved. Electricity is one of the most important achievements 
of our civilization's goals. For instance, solar energy is the only way to change towards sustainable and clean energy. The wind can be also a source of clean and sustainable energy. Moreover, the rivers can be used to get hydroelectric power or hydraulic power [33]. All of these resources are among the materials and the basic manner to contribute to the mitigation of climate change and they are realizable with financial resources and technologies. In Madagascar, their richness of resources and its climate season combine with the effective application of the Paris Agreement might be a strong power and an effective contribution to fighting against climate degradation and climate change in the purpose to save this planet.

\section{Barriers to Mitigate Climate Change in Madagascar}

\subsection{Lack of Financial Fund}

Madagascar objectives for the mitigation of climate change remain conditioned by financial support, which will be received from global partners whatever if it is with conditional contributions and that is in line with the Paris Agreement article 9 that says "Developed country Parties shall provide financial resources to assist developing country Parties with respect to both mitigation and adaptation in continuation of their existing obligations under the Convention." Also in this article 9 paragraph 3 "As part of a global effort, developed country Parties should continue to take the lead in mobilizing climate finance from a wide variety of sources, instruments, and channels, noting the significant role of public funds, through a variety of actions, including supporting country-driven strategies and taking into account the needs and priorities of developing country Parties. Such mobilization of climate finance should represent a progression beyond previous efforts." The government of Madagascar estimates that the costs of the mitigation actions will be above 6 billion US dollars.

\subsection{Ancestral Culture Practices (Traditional Agriculture Systems)}

This practice is brought by boat from the Polynesian islands or from Africa, bringing with them a farming technique known as "Tavy". In practice of "Tavy", a farmer utilizes a little part of the forest, and burns it, and then, they plant rice that is irrigated by rainfall alone. After cropping the rice, the farmer and his family leave the forest fallow, sometimes for up to 20 years. However, without trees, the land cannot be watered properly and that portion of land becomes rapidly unusable, and over the generations, that might provoke global devastation on this island nation [34].

Although the forest destruction may have come about at the hand of the small farmer, unfortunately, it is because of the social, economic, political and historical factors mostly causing environmental degradation. About 80 percent of the population are subsistence farmers, many of whom depend entirely on "natural capital" to support their way of life [35]. Yet this way of life is time-limited: which means once the forest is destroyed or ruined so "Tavy" stops automatical- 
ly. However, many farmers keep doing this traditional slash practice and burn agriculture because it is their habit, and they know no other manner to gain their life.

At the moment the forest has redeveloped, plenty of nutrients are restored in the trunks, and these are released in the next slash and burn cycle of farming, providing fertilizer for the crop. This farming habit goes considerably and does not permanently damage the forest as long as domain dimensions are small and farmers leave enough time for re-growth. Nevertheless, if farmers re-use to the fallow fields too promptly, as they do when inhabitants densities progress, the soils become debilitated. And if a little forest is left in between fields, then there are no parent trees to provide seeds and seedlings to restore the forest. Eventually, vast areas of forest are transformed into wastelands, upon which nothing can grow such as rice, forest, etc. In these areas, farmers feed their cattle and keep burning the grasslands every year, to provide "greener grass" for the cattle [36].

The people in rural areas depend on the forest. In other ways, that entrains other threats to this remarkable significant resource. In the rainforest, nearby residents may use diverse species of fauna and flora, animals for food, shelter, firewood, medications, tissue, resin, production, house implements, and clothing. Sometimes, as in the case of the most sought-after species, over-collection or over-hunting is now leading to depletion and local extinction of precious biological and natural resources. Indeed, the disappearance of a large number of lemur species within the past several years may have been due to over-hunting by the inhabitants of Madagascar [37].

\subsection{Fuel Wood and Charcoal}

In Madagascar, charcoal provides about $90 \%$ of the energy used for daily life or cooking in urban households is provided by charcoal [38]. The spiny forest of the country is rapidly deforested and destroyed to produce more charcoal as people seek to gain money from producing and selling coal along every roadside. This practice is the most contributors to deforestation in Madagascar because it is the way that the people think to supply them in energy and answer to their needs. Energy policies supposed to balance forest ecosystem protection with meeting peoples' daily energy needs [39]. This protection of the ecosystem requires sustainable management of forests that are exploited for producing charcoal, the organization concerned to this try to fight the poverty since the charcoal business provides essential supplementary income for thousands of producers. Madagascar has implemented a domestic energy policy that enhances the energy supplies in particularly charcoal for the urban communities and also setting up a pathway for sustainable decentralized management of charcoal supplies in the cities existing in Madagascar [40].

The use of fuel wood and the practice of charcoal are often the source of soil erosion because with fewer trees to hold the soil in place and it would be easy for the land or soil to slide. Moreover, that is why in Madagascar, most of the topsoil 
on the country is surrounding by rivers and streams, and this widespread soil erosion will make the production of crops from depleted soils increasingly difficult in the future.

\subsection{Timber Logging}

Historically, the exportation of woods in Madagascar has been regulated by the Malagasy government, although the logging of precious woods was strictly prohibited from protected areas in 2000. For instance, due to the high value of Malagasy hardwoods such as ebony and rosewood, logging occurs throughout Madagascar, even in protected areas [41].

\subsection{Erosion}

With its rivers are considered as blood and coloring, the surrounding Indian Ocean that astronauts have referred that as if Madagascar is bleeding. This deep observation emphasizes one of Madagascar's greatest environmental problems soil erosion. This phenomenon of deforestation in central highlands of Madagascar, the combination of natural geologic and soil conditions, has provoked huge soil erosion, which in some areas may top 400 tons/ha per year. For Madagascar, a country that relies on agricultural production for the foundation of its economy, the loss of this soil is especially costly [42].

In another word, the natural catastrophes, like cyclones, floods, which drop extraordinary quantities of torrential rain, periodically ravage the island's interior, but there is also a catastrophe that created by the people through its daily activities.

Nowadays' climate degradation's impacts in Madagascar: this year of 2020 is marked by direct proof of climate change in Madagascar because during January and February all the regions have faced the tragedy of flood and drought.

Regarding these photos, Figure 1 shows the drought in south part of Madagascar was provoked by insufficient rain due to climate change and it has a crucial impact on the population around because in Figure 2, the people sell water in a cup or bowl. Moreover, in Figure 3, some cattle died by thirsty because of lack of water. Madagascar is a small country involved in dilemma of climate deregulation and now this cannot escape the impact of climate change due to the destruction of environment or nature.

\section{Recommendations and Needs to Mitigate Climate Change}

Madagascar needs to spend a substantial part of its annual budget on social services and infrastructures in response to the adverse effects of climate change. It is, however, worth noting that studies related to adaptation costs do not yet exist yet for Madagascar, it is needed to educate the nation for the negative impacts of climate change. Madagascar needs the implementation of the Intended Nationally Determined Contributions (INDC) with conditions by the availability of external financial support, especially through the financial mechanisms under the 


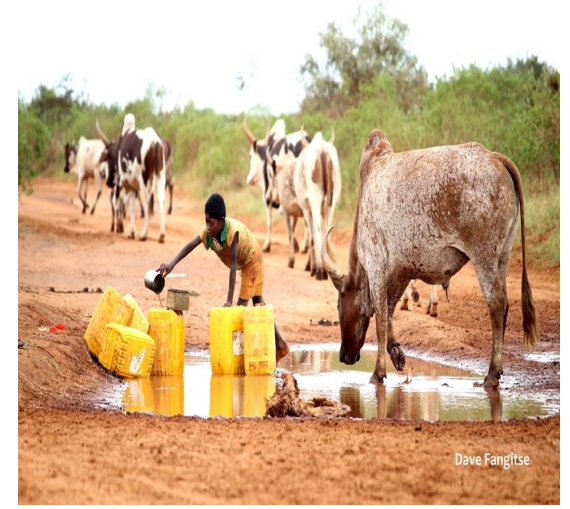

Figure 1. Drought. Source: DaveFangetse, 2020.

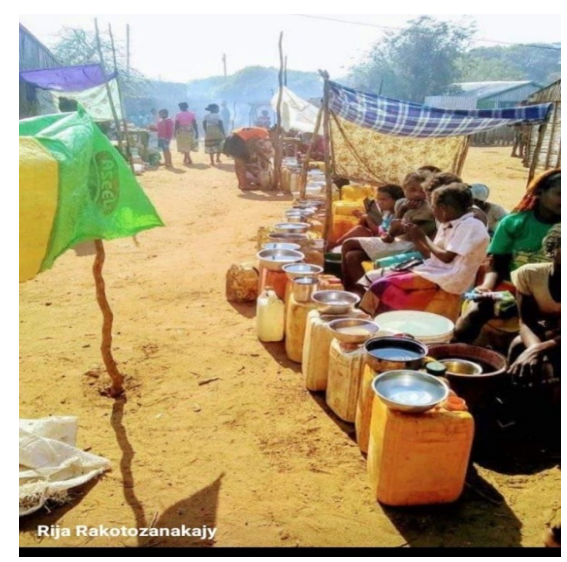

Figure 2. Selling water. Source: RijaRakotozanakajy, 2020.

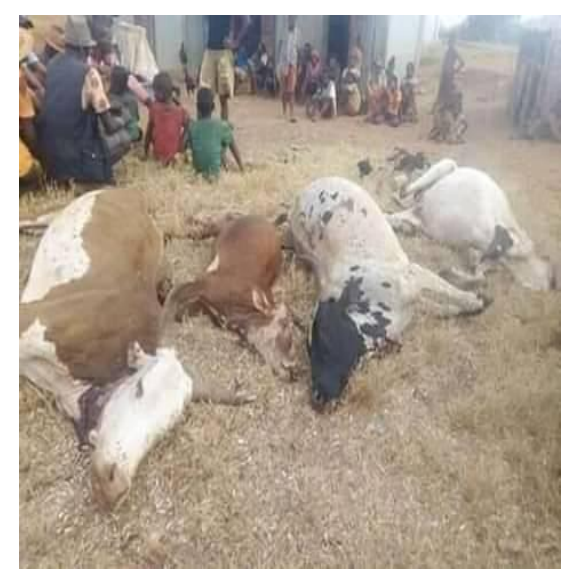

Figure 3. Cattle killed by thirsty. Source: Fab Kely, 2020.

United Nations Framework Convention on Climate Change (UNFCCC) but also through other multilateral and bilateral sources.

The effective implementation of Madagascar's contributions requires the reinforcement of the national capacities which means technical, institutional, 
mobilization and absorption of funding and transfer of technology and research from developed countries, as well as the contributions of countries and other stakeholders that are actively involved in the fight against climate change. Also, it needs the implementation of the actions of this INDC that estimated at USD 42.099 billion with these details: "For adaptation 28.713, for mitigation are 6.370, for capacities building 1.754 and for technology development and transfer, and research estimated to 5.262. Therefore the total estimated is 42.099 billion USD" [32]. On the basis of these external contributions and national contributions, it has set up national mechanism sustainability of actions against the climate change operational before the end of 2020 .

Finally, in order to demonstrate its commitment against climate change, the Republic of Madagascar with internal resources will contribute to the implementation of the actions of SCOND up $4 \%$ of the cost amounts. Madagascar has to create a sustainable national financial mechanism that will deal in particular with climate change and the mechanism should be operational by the end of 2020. In addition, the government will contribute, through the mobilization of domestic resources, up to $4 \%$ of the INDC implementation costs. This is the Actions required to be taken according to Madagascar's intended nationally determined contribution:

- Reinforcement of the National Adaptation Plan;

- Strengthen climate change adaptation mainstreaming in all strategic/framework documents;

- Multi-hazard early warning systems primarily that mainly consider cyclones, floods, drought, and public health surveillance;

- Effective application of existing or newly established sectorial policies: flood and cyclone-resistant hydro-agricultural infrastructures standards, cyclone-resistant buildings standards, flood-resistant terrestrial transport infrastructure standards, local for climate hazard community guideline for Water-Sanitation-Hygiene;

- A large scale of awareness-raising campaigns concerning the hostile effects of climate change and environmental degradation;

- Development of Resilient Agriculture Integrated Model pilot projects/programs (a combination of watershed management, selected/adapted varieties, locally-produced compost, rehabilitation of hydro-agricultural infrastructures, input access facilitation system, conservation agriculture, and agroforestry) or "climate-smart agriculture";

- Fostering of positive improvement of rice farming system and rain-fed rice farming technique;

- Preparation and implementation of the national policy of the maritime territory of Madagascar, without neglecting climate change;

- Formulation and implementation of the National Strategy for Integrated Water Resources Management;

- Evaluation of links for the climate change and migration of vector-borne 
diseases, malaria, and others emerging diseases as well as the evolution of acute respiratory infections, in order to identify remedial and/or corrective measures;

- Reestablishment of natural forests and solidify of habitat connectivity;

- Effective management of climate refuge areas inside and outside the protected zone;

- Contribution to the finalization of the "National framework for meteorological services" for which Madagascar has committed to the World Meteorological Organization.

Major mitigation actions, the Republic of Madagascar identified the following actions to contribute to the reduction of GHG emissions:

\subsection{In the Energy Sector}

- Facilitate access to energy by strengthening existing systems and by promoting renewable and alternative energies;

- Rehabilitate energy-producing network and plant stations;

- Give more consideration on renewable energy using hydraulic and solar energy from the current level of $35 \%$ to $79 \%$;

- Improve energy efficiency;

- Rural electrification;

- Make known improved stoves (by 2030: 50\% of households adopting improved stoves).

\subsection{In the Agriculture Sector}

- Large spread dissemination of intensive/effective rice farming techniques;

- Effective extension on the implementation of conservation agriculture and climate-smart agriculture;

- Spreading arboriculture (from 2018: 5,000 ha per year).

\subsection{Land Use, Land-Use Change, and Forestry Sectors}

- Massive reforestation for sustainable timber production and autochthonous species for conservation;

- Reduction of forest timber extraction;

- Large scale adoption of agroforestry;

- Forest and grassland forests enhanced monitoring.

\subsection{Waste}

- Biogas production from wastewater;

- Sustainable management (compost) of organic household waste $(50 \%$ of waste treated in urban agglomerations).

\subsection{Forestation}

The impact of the reforestation efforts is more considerable and remarkable in 
Madagascar [43]. It is stated that now more than 2 million trees planted to replenish widespread deforestation and the planted trees have created corridors of rain forest that connect mountaintops. Those trees have grown rapidly and can now help and contribute to mitigating global warming and climate degradation. It helps to tackle the massive deforestation that handicaps the island and to make the local population aware of the importance of biodiversity.

Table 1 shows Madagascar's numerous international environmental conventions, treaties and agreements; unfortunately, integration of the obligations conferred upon Madagascar by these treaties into the legislative framework has not been fully achieved.

After all circumstance that has met in this country, here below is a framework anticipated that might be a rapid remedy to mitigate and improve the climate situation in Madagascar.

Regarding this Figure 4, an integrated conservation supported by financial fund or capacity well managed by policy makers and population combined with strong policies will result in rapid improvement and can decline the massive progression of deforestation or environmental degradation.

\section{Conclusion}

The government of Madagascar recognized that environmental degradation posed an enormous threat both to its human population, to its biodiversity, particularly the entire planet. With the help of multi-national donors, government agencies and non-governmental organizations in line with the application of the Paris Agreement, the Malagasy government forged a document known as the

Table 1. Madagascar's international environmental agreements.

\begin{tabular}{cc}
\hline Name of Agreement & $\begin{array}{c}\text { Year entered } \\
\text { into Force }\end{array}$ \\
\hline $\begin{array}{c}\text { Convention on Fishing and Conservation of Living Resources of the High Seas } \\
\text { Conservation of Wetlands of International Importance (Ramsar Convention) }\end{array}$ & 1966 \\
$\begin{array}{c}\text { Conservation on the International Trade in Endangered Species of Wild Flora } \\
\text { and Fauna (CITES) }\end{array}$ & 1975 \\
Vienna Convention for the Protection of the Ozone Layer & 1988 \\
$\begin{array}{c}\text { Montreal Protocol on Substances that Deplete the Ozone Layer } \\
\text { Basel Convention on the Control of Transboundary Movements of }\end{array}$ & 1989 \\
Convention on Biological Diversity & 1992 \\
United Nations Convention on the Law of the Sea & 1993 \\
United Nations Convention to Combat Desertification & 1994 \\
Kyoto Protocol to the UNFCCC & 1996 \\
Paris agreement & 2005 \\
\hline
\end{tabular}

Source: CIA World Factbook, 2012. 


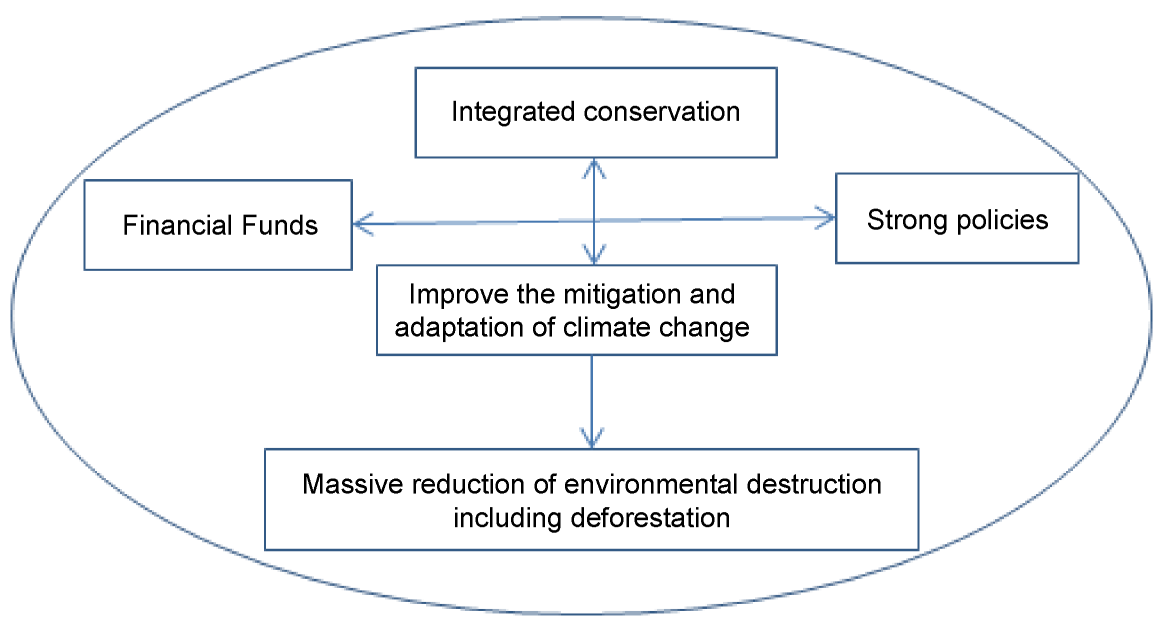

Figure 4. Framework for promoting conservation of environment in Madagascar. Source: Author's concept, 2020.

National Environmental Action Plan. Now the concern should be how to slow this ecological decline and how to best utilize lands already degraded so they support productive activities today and for future generations. Without improving the well-being of the average Madagascar people, we cannot expect too much result of conservation and development. To conserve biodiversity, we need to take into consideration the integrated conservation and development approach; it means the local people living around or nearby the forest or parks are requisite to participate in the conservation as well as the entire nation. It is felt that the term "natural catastrophe" should be changed to "catastrophe created" because what appears to be environmental degradation is due to our own actions.

\section{Conflicts of Interest}

The authors declare no conflict of interest.

\section{Acknowledgements}

The authors would like to thank our college and our respectable teachers for the knowledge and support. We are also grateful to the anonymous reviewers for their valuable time, constructive and helpful comments and suggestions which encouraged us to finalize this work.

\section{References}

[1] Kahn, M.E. (2009) Urban Growth and Climate Change. Annual Review of Resource Economics, 1, 333-350. https://doi.org/10.1146/annurev.resource.050708.144249

[2] Achard, F., et al. (2002) Determination of Deforestation Rates of the World's Humid Tropical Forests. Science, 297, 999-1002. https://doi.org/10.1126/science.1070656

[3] Wright, S.J. and Muller-Landau, H.C. (2006) The Future of Tropical Forest Species. Biotropica, 38, 287-301. https://doi.org/10.1111/j.1744-7429.2006.00154.x

[4] Blake, S., et al. (2007) Forest Elephant Crisis in the Congo Basin. PLoS Biology, 5, 
e111. https://doi.org/10.1371/journal.pbio.0050111

[5] United Nations (2005) Climate Change Vulnerability in Africa. https://www.grida.no/resources/7721

[6] Low, P.S. (2005) Climate Change and Africa. Cambridge University Press, Cambridge. https://doi.org/10.1017/CBO9780511535864

[7] Allnutt, T.F., et al. (2008) A Method for Quantifying Biodiversity Loss and Its Application to a 50-Year Record of Deforestation across Madagascar. Conservation Letters, 1, 173-181.

[8] Goodman, S.M. and Benstead, J.P. (2005) Updated Estimates of Biotic Diversity and Endemism for Madagascar. ORYX,. https://doi.org/10.1017/S0030605305000128

[9] Ganzhorn, J.U., Lowry, P.P., Schatz, G.E. and Sommer, S. (2001) The Biodiversity of Madagascar: One of the World's Hottest Hotspots on Its Way Out. Oryx, 39, 73-77. https://doi.org/10.1017/S0030605300032117

[10] Hannah, L., et al. (2008) Climate Change Adaptation for Conservation in Madagascar. Biology Letters, 4, 590-594.

[11] Global Forest Watch (2018) Deforestation Statistics for Madagascar. https://rainforests.mongabay.com/deforestation/archive/Madagascar.htm

[12] Protected Planet (2017) Madagascar, Africa. https://www.protectedplanet.net/country/MDG

[13] German Advisory Council on Global Change (2011) World in Transition. A Social Contract for Sustainability.

[14] Timasheff, N.S. (1950) Social Theory and Social Structure. Thought, 25, 124-125. https://doi.org/10.5840/thought195025111

[15] Social Science (2019) Social Change-Population, Urbanization, and Social Movements.

https://socialsci.libretexts.org/Bookshelves/Sociology/Book\%3A_Sociology_(Barkan $\underline{\text { )/13.6\%3A_End-of-Chapter_Material }}$

[16] Ingram, J.C. and Dawson, T.P. (2005) Climate Change Impacts and Vegetation Response on the Island of Madagascar. Philosophical Transactions of the Royal Society A: Mathematical, Physical and Engineering Sciences, 363, Issue 1826. https://doi.org/10.1098/rsta.2004.1476

[17] Kremen, C. (2014) Biological Inventory Using Target Taxa: A Case Study of the Butterflies of Madagascar. Ecological Applications, 4, 407-422. https://doi.org/10.2307/1941946

[18] Kremen, C. (2000) Traditions That Threaten. http://www.pbs.org/edens/madagascar/paradise.htm

[19] Smith, T. (2012) The Role of Forests in Combating Climate Change. https://www.climatechangenews.com/2012/09/30/why-are-forests-important-for-cli mate-change/

[20] Lackner, K.S., Grimes, P. and Ziock, H.J. (2014) Capturing Carbon Dioxide from Air. In: Carbon Capture and Storage: $\mathrm{CO}_{2}$ Management Technologies, Apple Academic Press, 364-376. https://doi.org/10.1201/b16845 https://asu.pure.elsevier.com/en/publications/capturing-carbon-dioxide-from-air

[21] Ehleringer, J.R., Sage, R.F., Flanagan, L.B. and Pearcy, R.W. (1991) Climate Change and the Evolution of C4 Photosynthesis. Trends in Ecology and Evolution, 6, 95-99. https://doi.org/10.1016/0169-5347(91)90183-X

[22] Ratsimbazafy, C., Newton, D.J. and Ringuet, S. (2016) Timber Island: The Rose- 
wood and Ebony Trade of Madagascar. No. December, p. 144.

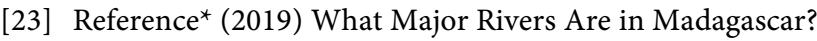
https://www.reference.com/article/major-rivers-madagascar-1aecff2540c2796a?aq= what + major+rivers+are + in + Madagascar \&qo $=$ cdpArticles

[24] Iryo, T., Afif, M., Chen, R. and Penttinen, S. (2010) Design and Construction of Tailings Dams in Madagascar Tropical Wet Conditions for the Ambatovy Project. Canadian Dam Association 2010 Annual Conference, 14 p. https://www.mendeley.com/catalogue/3a812544-81b8-3e6e-82d6-cclee2052076/

[25] World Data Atlas (2015) Madagascar-Total Dam Capacity. https://knoema.com/atlas/Madagascar/topics/Water/Dam-Capacity/Total-dam-cap acity

[26] Meijer, L.J.J., Van Der Ent, R.J., Hoes, O.A.C., Mondeel, H. and Van De Giesen, N.C. (2012) World Hydropower Capacity Evaluation. Semantic Scholar.

https://repository.tudelft.nl/islandora/object/uuid\%253A49d8d013-9a48-4222-85a10ebb53f83dc8/?collection=research

[27] Gade, D.W. (1996) Deforestation and Its Effects in Highland Madagascar. Mountain Research and Development, 16, 101-116. https://doi.org/10.2307/3674005

[28] Spark, W. (2019) Average Weather in Toamasina. https://weatherspark.com/y/104761/Average-Weather-in-Toamasina-Madagascar-Y ear-Round

[29] Weather \& Climate (2019) Climate and Average Monthly Weather in Toamasina, Madagascar.

https://weather-and-climate.com/average-monthly-Rainfall-Temperature-Sunshine, Toamasina,Madagascar

[30] Harper, G.J., Steininger, M.K., Tucker, C.J., Juhn, D. and Hawkins, F. (2007) Fifty Years of Deforestation and Forest Fragmentation in Madagascar. Environmental Conservation, 34, 325-333. https://doi.org/10.1017/S0376892907004262

[31] USAID (2019) Environment and Climate Change. https://www.usaid.gov/madagascar/environment

[32] Government of Madagascar (2010) Madagascar's Intended Nationally Determined Contribution. 1-13.

https://www4.unfccc.int/sites/ndcstaging/PublishedDocuments/Madagascar\%20Firs t/Madagascar\%20INDC\%20Eng.pdf

[33] CIF (2013) Climate Investment Funds. https://www.climateinvestmentfunds.org/sites/cif_enc/files/knowledge-documents/ climate_investment_funds_brochure.pdf

[34] Scales, I.R. (2014) The Drivers of Deforestation and the Complexity of Land Use in Madagascar. In: Scales, I.R., Ed., Conservation and Environmental Management in Madagascar, Routledge, Abingdon-on-Thames, 105-126.

[35] Styger, E., Rakotondramasy, H.M., Pfeffer, M.J., Fernandes, E.C.M. and Bates, D.M. (2007) Influence of Slash-and-Burn Farming Practices on Fallow Succession and Land Degradation in the Rainforest Region of Madagascar. Agriculture, Ecosystems \& Environment, 119, 257-269. https://doi.org/10.1016/j.agee.2006.07.012

[36] Kull, C.A. (2000) Deforestation, Erosion, and Fire: Degradation Myths in the Environmental History of Madagascar. Environment and History, 6, 423-450. https://doi.org/10.3197/096734000129342361

[37] Mittermeier, R.A., et al. (2008) Lemur Diversity in Madagascar. International Journal of Primatology, 29, 1607-1656. https://doi.org/10.1007/s10764-008-9317-y 
[38] Gade, D.W. and Perkins-Belgram, A.N. (1986) Woodfuels, Reforestation, and Ecodevelopment in Highland Madagascar. GeoJournal, 12, 365-374.

https://doi.org/10.1007/BF00262359

[39] Cirad (2011) Charcoal in Madagascar: Reconciling Urban Demand and Sustainable Management.

https://www.cirad.fr/en/our-research/research-results/2010/charcoal-in-madagascar

[40] Randriamalala, J.R., Radosy, H.O., Razanaka, S., Randriambanona, H. and Hervé, D. (2016) Effects of Goat Grazing and Woody Charcoal Production on Xerophytic Thickets of Southwestern Madagascar. Journal of Arid Environments, 128, 65-72. https://doi.org/10.1016/j.jaridenv.2016.01.002

[41] Innes, J. (2010) Madagascar Rosewood, Illegal Logging and the Tropical Timber Trade. Madagascar Conservation \& Development, 5, No. 1.

https://doi.org/10.4314/mcd.v5i1.57335

[42] Randrianarijaona, P. (1983) Erosion of Madagascar. Ambio, 12, 308-311.

[43] Manjaribe, C., Frasier, C.L., Rakouth, B. and Louis, E.E. (2013) Ecological Restoration and Reforestation of Fragmented Forests in Kianjavato, Madagascar. International Journal of Ecology, 2013, Article ID: 726275.

https://doi.org/10.1155/2013/726275

\section{Abbreviations and Acronyms}

BAU: Business As Usual

CARE: Cooperative for Assistance and Relief Everywhere, formerly Cooperative for American Remittances to Europe

CITES: Conservation on the International Trade in Endangered Species of Wild Flora and Fauna

$\mathrm{CO}_{2}$ : Carbon Dioxide

GHG: Green House Gas

INDC: Intended National Determined Contributions

LULUCF: Land Use Land Use Change Forestry

$\mathrm{MtCO}_{2}$ : Metric Tons of Carbon Dioxide

UNEP-WCMC: United Nations Environment Protection-World Conservation Monitoring Centre

UNFCCC: United Nations Framework Convention on Climate Change 